\title{
DEKLARACJE INTERPRETACYJNE JAKO INSTRUMENT TRANSFORMACJI MIĘDZYNARODOWEGO PRAWA INWESTYCYJNEGO. KU OGRANICZENIU AKTYWIZMU SĘDZIOWSKIEGO
}

\section{WPROWADZENIE}

Międzynarodowe prawo inwestycyjne przynajmniej od dekady jest przedmiotem znaczącej krytyki ze strony państw, organizacji międzynarodowych, organizacji pozarządowych oraz części przedstawicieli świata nauki. Krytyka ta w znacznym stopniu odnosi się do sposobu orzekania trybunałów arbitrażowych funkcjonujacych na podstawie traktatów inwestycyjnych ${ }^{1}$. Problem ten dotyka również Polskę. Według Konferencji Narodów Zjednoczonych ds. Handlu i Rozwoju (UNCTAD) Polska znalazła się wśród 10 państw najczęściej skarżonych w arbitrażu inwestycyjnym w latach 1987-2017 (26 spraw) ${ }^{2}$, a według Prokuratorii Generalnej Rzeczypospolitej Polskiej w latach 2006-2019 Polska była pozwanym 28 razy $^{3}$.

W rezultacie zarówno państwa, jak i organizacje międzynarodowe poszukuja środków ograniczenia aktywizmu sędziowskiego tych trybunałów. Do najczęściej stosowanych mechanizmów w tym zakresie zalicza się renegocjacje istniejących traktatów inwestycyjnych, zawieranie nowych porozumień zawierających szczegółowe, precyzyjne normy znacznie ograniczające swobodę sędziowskiej interpretacji, jak również wypowiadanie istniejących traktatów w sytuacji znaczących trudności w obronie uprawnień regulacyjnych państwa w świetle ich postanowień ${ }^{4}$. Mechanizmy te, zasadniczo najbardziej pożądane i gwarantujące największą pewność w zakresie praw i obowiązków, posiadają również istotne mankamenty: z jednej strony bowiem wypowiedzenie traktatu inwestycyjnego po odpowiednim upływie czasu powoduje zakończenie jego

${ }^{1}$ Przez pojęcie „traktat inwestycyjny”, za UNCTAD, rozumie się dwustronną umowę o ochronie i popieraniu inwestycji lub traktat (np. ustanawiający strefę wolnego handlu) zawierający postanowienia dotyczące ochrony inwestycji, zob. <https://investmentpolicyhubold.unctad.org/IIA >

${ }^{2}$ IIA Issues Note, Investor-state dispute settlement: Review of developments in 2017, June 2018, issue 2: 3 .

${ }^{3}$ Druk sejmowy nr 3164 z 23 stycznia 2019 r.: 7.

${ }^{4}$ Szerzej zob. UNCTAD's Reform Package for the International Investment Regime, Geneva 2018: 77-92. 
obowiązywania, z drugiej - aktywuje zawartą w nim klauzulę przedłużonego obowiązywania. Zakłada ona, że wypowiedziany traktat nadal stosuje się w całości od 5 do nawet 25 lat, w zależności od konkretnej umowy ${ }^{5}$. Modyfikacja traktatu lub zawarcie nowego traktatu dwustronnego wymaga uciążliwych i potencjalnie długotrwałych negocjacji ${ }^{6}$ oraz przeprowadzenia odpowiednich procedur konstytucyjnych, które również mogą okazać się niełatwe ${ }^{7}$. W przypadku państw członkowskich UE trudność tę (czy też czas trwania ewentualnego procesu, zawierania nowej umowy inwestycyjnej lub renegocjacji istniejącej) pogłębia dodatkowo prawo UE wymagajace uzyskania uprzedniej zgody Komisji Europejskiej zgodnie z rozporządzeniem Parlamentu Europejskiego i Rady (UE) nr 1219/2012 z 12 grudnia 2012 r. ustanawiajacym przepisy przejściowe w zakresie dwustronnych umów inwestycyjnych między państwami członkowskimi a państwami trzecimi ${ }^{8}$.

Mając na względzie powyższe, niniejszy artykuł postuluje, że w ograniczeniu aktywizmu sędziowskiego w międzynarodowym prawie inwestycyjnym mogłyby znaczaco pomóc deklaracje interpretacyjne ${ }^{9}$. Mimo że nie zapewniaja one takiej pewności prawnej, jak wynegocjowanie nowego, bardziej precyzyjnego traktatu, to jednak z uwagi na relatywna łatwość ich uzgodnienia i akceptacji deklaracje te pozwalają znacznie szybciej osiagnąć pewien skutek prawny w zakresie interpretacji traktatu zgodnie z intencja jego stron.

$\mathrm{W}$ tym miejscu należy poczynić pewne wyjaśnienia terminologiczne. Pojęcie deklaracji interpretacyjnych jest w literaturze prawnomiędzynarodowej stosowane przede wszystkim $\mathrm{w}$ odniesieniu do deklaracji jednostronnych ${ }^{10}$. Natomiast wspólne deklaracje interpretacyjne wszystkich stron umowy sa traktowane jako późniejsze porozumienia (ang. subsequent agreements) zgod-

5 Zob. szerzej Kułaga (2018): 107-111.

${ }^{6}$ Przykładowo w lipcu 2016 r. w uzasadnieniu projektu zarządzenia Prezesa Rady Ministrów w sprawie Międzyresortowego Zespołu do spraw prawno-międzynarodowych aspektów polityki inwestycyjnej Rzeczypospolitej Polskiej znalazła się informacja, że Polska przystępuje do negocjacji umowy inwestycyjnej z Etiopia, zob. <https://www.google. com/search?ei=b-BZXJ-7E4vykgXcw7yQCw\&q=\%22Obecnie+Rzeczpospolita+Polska+przyst\%C4\%99puje+do+negocjacji+umowy+z+Etiopi\%C4\%85\%22\&oq=\%22Obecnie+Rzeczpospolita+Polska+przyst\%C4\%99puje+do+negocjacji+umowy+z+Etiopi\%C4\%85\%22\&gs_l=psy-ab.3...25050.27702..27943...0.0..0.92.163.2.........1..gws-wiz......0i71.FEGMT7AR4Rw>. Umowa jak dotąd nie została wynegocjowana.

7 Sejm RP 6 października 2016 r. przyjął uchwałę w sprawie kompleksowej umowy gospodarczo-handlowej [dalej jako: CETA] między Kanada, z jednej strony, a Unią Europejską i jej państwami członkowskimi z drugiej strony, w której wskazał, że związanie się umową CETA powinno nastapić w trybie art. 90 Konstytucji RP, M.P. 2016, poz. 985.

${ }^{8}$ Dz. Urz. UE L 351 z 20 grudnia 2012: 40-46 (dalej jako: rozporządzenie nr 1219/2012). Zgodnie z art. 9 ust. 3 tego rozporządzenia Komisja podejmuje decyzję upoważniającą państwo do podjęcia negocjacji umowy inwestycyjnej z państwem trzecim w terminie 90 dni od otrzymania wniosku. „Jeżeli do podjęcia decyzji niezbędne są dodatkowe informacje, bieg terminu 90 dni rozpoczyna się w dniu otrzymania dodatkowych informacji”.

9 Podobnie Ishikawa (2014): 32-33.

${ }^{10}$ Cameron (2006): $§ 1$. Podobnie Komisja Prawa Międzynarodowego w pracach dotyczących zastrzeżeń - Guide to Practice on Reservations to Treaties, Report of the International Law Commission 2011, A/66/10/Add.1: 115-117. W polskiej literaturze zob. m.in. Wyrozumska (2006): 247-250; Krzan (2009): 321-331; Burek (2012): 35-36. 
nie $\mathrm{z}$ art 31 . ust. 3 lit. a) Konwencji wiedeńskiej o prawie traktatów ${ }^{11}$. Z tego względu odpowiednie postanowienia KWPT będą przedmiotem pogłębionej analizy w niniejszym artykule. Równocześnie zdecydowano się utrzymać termin „deklaracja” jako adekwatnie odzwierciedlający specyfikę formy prawnej uzgodnień interpretacyjnych, przedstawionych w artykule zarówno z perspektywy prawa międzynarodowego, jak i prawa polskiego, a także prawa UE. Późniejsze porozumienia, o których mowa w art. 31 ust. 3 lit a) KWPT, moga, choć nie muszą, mieć charakter wiążący per se. Pojęcie deklaracji interpretacyjnej jest stosowane w niniejszym artykule w celu podkreślenia skoncentrowania analizy badawczej tylko na późniejszych porozumieniach, które nie są traktatami. Artykuł składa się z trzech podstawowych części: w pierwszej przedstawiono problem aktywizmu sędziowskiego w międzynarodowym prawie inwestycyjnym, jego przyczyny, podstawowe przejawy i konsekwencje dla państw; następnie omówiono konstrukcję deklaracji interpretacyjnych i ich znaczenie w prawie międzynarodowym, w trzeciej - pokazano możliwości zastosowania deklaracji interpretacyjnych w obszarze międzynarodowego prawa inwestycyjnego, w szczególności jako odpowiedź na aktywizm sędziowski w tym dziale prawa.

\section{AKTYWIZM SECDZIOWSKI W MIĘDZYNARODOWYM PRAWIE INWESTYCYJNYM}

Jak wskazywał Lech Morawski, od wielu lat dostrzegany jest rosnacy aktywizm sądów na całym świecie ${ }^{12}$. Zdaniem tego autora „dla wszystkich form aktywizmu charakterystyczne jest to, iż sędziowie tworzą nowe lub modyfikują istniejace reguły prawne lub też wykraczają poza swoje wyznaczone konstytucyjnie lub ustawowo funkcje" ${ }^{13}$. W tym kontekście warto odnotować, że specyfiką prawa międzynarodowego jest znacznie większa niedookreśloność norm aniżeli w przypadku prawa krajowego ${ }^{14}$. W rezultacie naturalne jest, że sądy międzynarodowe korzystają z większej swobody interpretacyjnej $\mathrm{w}$ porównaniu z sądami krajowymi ${ }^{15}$. Teza ta znajduje szczególne odzwierciedlenie w międzynarodowym prawie inwestycyjnym, w którym trybunały arbitrażowe orzekają na podstawie dwustronnych traktatów inwestycyjnych

${ }^{11}$ Dz. U. 1990, Nr 74, poz. 439, załącznik (dalej jako: KWPT).

${ }^{12}$ Morawski (2005): 285; podobnie Kaufmann-Kohler (2007): 359.

${ }^{13}$ Morawski (2005): 291.

${ }^{14}$ Zdanie odrębne sędziego TK Mirosława Granata do uzasadnienia wyroku TK z 24 listopada 2010 r., K 32/09, pkt 4.

${ }^{15}$ Jak wskazuje Anna Wyrozumska: „niekompletność norm prawa międzynarodowego, wielość wersji językowych tekstów prawnych, wieloznaczność użytych sformułowań, a także multikulturowość, w jakiej prawo powstaje i funkcjonuje, powoduje, że sędzia międzynarodowy korzysta $\mathrm{z}$ większej swobody interpretacyjnej aniżeli sędzia krajowy orzekający na podstawie prawa krajowego" - Wyrozumska (2014): 23; zob. również Roberts (2010): 187-189; Balcerzak (2008): $65-79$. 
charakteryzujących się daleko posuniętą lakonicznością ${ }^{16}$. Brak apelacji oraz stałych sędziów powoduje dodatkowo istotne trudności co do przewidywalności danego rozstrzygnięcia, gdyż metodologia stosowana przez inwestycyjne trybunały arbitrażowe jest niezwykle różnorodna ${ }^{17}$. W rezultacie część trybunałów uznaje za istotne dokonywanie interpretacji traktatów inwestycyjnych przez odwoływanie się do orzecznictwa sformułowanego przez organy rozstrzygania sporów Światowej Organizacji Handlu ${ }^{18}$, inne natomiast częściej odwołują się do orzecznictwa Europejskiego Trybunału Praw Człowieka, czy nawet do rozwiązań prawa krajowego niektórych państw (szczególnie anglosaskich $)^{19}$. Wszystkie natomiast inwestycyjne trybunały arbitrażowe odwołują się do orzecznictwa innych tego rodzaju trybunałów, dążąc do osiagnięcia pewnej spójności z wcześniejszymi rozstrzygnięciami, mimo że doktryna stare decisis nie obowiąuje w prawie międzynarodowym ${ }^{20}$. Podejście takie jest tym bardziej zaskakujące, że trybunały te rozstrzygają na podstawie różnych traktatów, które zawieraja podobne, ale nie identyczne postanowienia, i których szersze ramy prawne - rozumiane zgodnie $\mathrm{z}$ art. 31 ust. $3 \mathrm{KWPT}-\mathrm{z}$ założenia nie sa jednakowe ${ }^{21}$. Dobrze ten problem oddaje Anathea Roberts, według której: „Orzecznictwo [...] tworzy wrażenie zamkniętego sprzężenia zwrotnego pomiędzy trybunałami oraz opiniami naukowców, nieograniczonego przez praktykę stron traktatu czy ich oczekiwania"22.

Z tej perspektywy arbitraż inwestycyjny wpisuje się w dostrzeżone już przez doktrynę zjawisko „multiplikacji sądów międzynarodowych” i wiążące się z tym ściśle zagadnienie wzajemnych relacji pomiędzy trybunałami międzynarodowymi a ich orzecznictwem ${ }^{23}$. Jednocześnie należy wyjaśnić, że krytyka aktywizmu

${ }^{16}$ Warto jednak odnotować, że zwłaszcza traktaty zawarte w ostatniej dekadzie uległy istotnemu przeobrażeniu polegającemu na znaczącemu zwiększenie precyzji ich postanowień. Wynikało to z zaniepokojenia rozszerzającą wykładnią stosowaną przez trybunały arbitrażowe (zob. szerzej Kułaga [2016]: 31-46). Niemniej zasadnicza większość obowiąujących dwustronnych umów inwestycyjnych przewidujących arbitrażowy mechanizm rozwiązywania sporów to umowy starego typu, pozostawiające arbitrom niemal nieograniczoną swobodę w zakresie ustalania praw i obowiązków zawartych w traktacie - zob. UNCTAD, World Investment Report 2015: Reforming International Investment Governance, Geneva-New York 2015: 121.

17 Cho, Kurtz (2018): 185-186 i 197-198.

18 Alvarez, Brink (2010): $11 \mathrm{i} \mathrm{n}$.

19 Schneiderman (2008): 107-191.

20 „Trybunały arbitrażowe działające w ramach Międzynarodowego Centrum Rozwiązywania Sporów Inwestycyjnych (ICSID) mają charakter ad hoc [...], a niniejszy trybunał nie zna przepisu [...] ustanawiającego obowiązek przestrzegania doktryny stare decisis. Niemniej rozsądne jest założenie, że trybunały arbitrażowe, szczególnie te ustanowione w ramach systemu ICSID, będą generalnie brały pod uwagę precedensy ustanowione przez inne organy arbitrażowe" (tłum. Ł.K.), decyzja dot. jurysdykcji w sprawie El Paso Energy International Co. przeciwko Argentynie, ICSID Case ARB/03/15, 27 kwietnia 2006 r., § 39; podobnie m.in. trybunał w sprawie LETCO przeciwko Liberii, wyrok z 31 marca 1986 r., ICSID Reports 1986 r., § 352, w sprawie Bayindir Insaat Turizm Ticaret Ve Sanayi AS przeciwko Pakistanowi, decyzja dot. jurysdykcji z 14 listopada 2005 r., § 76; zob. szerzej Schreuer, Weiniger (2008): 1189; Cheng (2009): 163; Reinisch (2009): 903.

21 Schill (2010): 21; Fauchald (2008): 334; Kill (2008): 864-865.

22 Roberts (2010): 190 (tłum. Ł.K.).

${ }^{23}$ Krzan (2015): 250-261 i cytowane tamże poglądy doktryny. 
sędziowskiego, w szczególności w międzynarodowym prawie inwestycyjnym, wynika z nadmiernego uwypuklenia w nim interesów inwestorów zagranicznych względem innych istotnych wartości, przede wszystkim takich jak ochrona środowiska czy ochrona praw człowieka, realizowanych przez państwa na podstawie ich uprawnień regulacyjnych. W rezultacie dla uzyskania większej pewności i przejrzystości aktualnych zobowiązań międzynarodowych oraz dla ochrony swoich legitymizowanych interesów państwa powinny podjąć proaktywne działania w odniesieniu do traktatów inwestycyjnych, którymi są związane. Jak wskazano wcześniej, deklaracje interpretacyjne moga być jednym z istotnych instrumentów w tym zakresie ${ }^{24}$. Dobrze oddaje tę ideę rozstrzygnięcie zapadłe w sprawie Methanex przeciwko Stanom Zjednoczonym: „Jeżeli ustawodawca po uchwaleniu ustawy ma wrażenie, że sądy ją implementujące przeinaczyły intencję ustawodawcy, jest całkowicie właściwe, aby ustawodawca wyjaśnił swoja intencję. W demokratycznym i reprezentatywnym ustroju, w którym władza ustawodawcza odzwierciedla wolę ludu, wydaje się, że wyjaśnienie ustawodawcze tego rodzaju jest obowiązkowe. Sąd nie widzi powodów, dlaczego ta sama ocena nie miałaby mieć zastosowania do prawa międzynarodowego"25.

\section{DEKLARACJE (POROZUMIENIA) INTERPRETACYJNE W ŚWIETLE PRAWA MIĘDZYNARODOWEGO}

\section{Uwarunkowania ogólne}

Zgodnie z art. 31 KWPT - odzwierciedlajacym normy międzynarodowego prawa zwyczajowego ${ }^{26}$ _, ,Traktat należy interpretować w dobrej wierze, zgodnie ze zwykłym znaczeniem, jakie należy przypisywać użytym w nim wyrazom w ich kontekście, oraz w świetle jego przedmiotu i celu” (ust. 1). Dodatkowo art. 31 ust. 3 lit a) KWPT określa, że: „Łącznie z kontekstem należy brać pod uwagę: a) każde późniejsze porozumienie między stronami, dotyczace interpretacji traktatu lub stosowania jego postanowień”.

Komisja Prawa Międzynarodowa (KPM) która przygotowała projekt KWPT, w komentarzu do projektu art. 27 (który następnie w całości został

${ }^{24}$ Artykuł koncentruje się na deklaracjach wszystkich stron umowy jako potencjalnie mających największe znaczenie prawne Nie oznacza to jednak, że bez znaczenia prawnego pozostaja jednostronne deklaracje interpretacyjne. W sytuacji niemożliwości uzyskania porozumienia co do deklaracji wszystkich stron, deklaracje jednostronne również powinny być wykorzystywane przez państwa. Zob. przykładowo deklarację zawartą w notyfikacji Polski informujaccą stronę niderlandzką o wypowiedzeniu dwustronnej umowy inwestycyjnej, Dz. U. 2019, poz. 206.

25 Sprawa Methanex przeciwko Stanom Zjednoczonym, wyrok z 3 sierpnia 2005 r., § 22, <http://www.state.gov/s/l/c3741.htm> (tłum. Ł.K.).

${ }^{26}$ Stanowisko to zostało potwierdzone w orzecznictwie sądów międzynarodowych, zob. szerzej Raport Komisji Prawa Międzynarodowego z 2018 r., A/73/10, Yearbook of the International Law Commission 2018, vol. 2 (Part Two): 18-19. 
przeniesiony do art. 31 ostatecznego tekstu KWPT), podkreśliła, że wyraz „kontekst” w art. 31 ust. 3 został użyty, „aby inkorporować do ust. 1 elementy interpretacyjne określone w ust. 3”. Potwierdziła tym samym, że art. 31 określa jedna, a nie wiele reguł interpretacji, tak aby „proces interpretacji był jednością"27. Prawo międzynarodowe nie określa żadnych szczegółowych wytycznych, jak należy rozumieć termin „późniejsze”. Niemniej przyjmuje się, że wystarczy, aby porozumienie takie zostało przyjęte po podpisaniu traktatu ${ }^{28}$. Istotne jest również, aby porozumienie „dotyczyło” interpretacji lub stosowania traktatowych postanowień. Jego treść powinna zatem wskazywać, że jego celem jest wyjaśnienie znaczenia traktatu ${ }^{29}$.

Równocześnie KPM uznała późniejsze porozumienia za „autentyczny środek interpretacji”, tj. potwierdziła, że wspólna wola stron, która legła u podstaw zawarcia traktatu, posiada szczególny autorytet w zakresie identyfikacji znaczenia tego traktatu, nawet po jego zawarciu ${ }^{30}$. Komisja zauważyła również, że do późniejszych porozumień ma zastosowanie teza zawarta w wyroku Międzynarodowego Trybunału Sprawiedliwości (MTS) ze sprawy Ambatielos, który w kontekście porozumienia towarzyszącego zawarciu traktatu stwierdził, że: „postanowienia Deklaracji maja charakter klauzuli interpretacyjnej i jako takie powinny być postrzegane jako integralna część traktatu"31.

W tym kontekście przypomnieć należy, że zawarty w art. 31 ust. 3 termin „porozumienie” nie oznacza, iż przyjęty dokument musi mieć per se charakter formalnie wiążący. W zakończonych w 2018 r. pracach nad zagadnieniem „Późniejsze porozumienia i późniejsza praktyka w relacji do interpretacji traktatów” KPM zauważyła: „Porozumienie w świetle art. 31 ust. 3 lit. (a) i (b) wymaga wspólnego rozumienia dotyczącego interpretacji traktatu, którego strony są świadome i które akceptują. Takie porozumienie może, ale nie musi, być prawnie wiążące, aby zostało wzięte pod uwagę" (konkluzja 10 ust. 1) ${ }^{32}$. W komentarzu do tej konkluzji KPM podniosła, że pojęcie porozumienia w KWPT

${ }^{27}$ Draft Articles on the Law of Treaties with commentaries 1966, Yearbook of the International Law Commission 1966, vol. 2: 220.

${ }^{28}$ Dorr, Schmalenbach (2012): 553.

${ }^{29}$ Raport KPM 2018: 30-31; podobnie Linderfalk (2007): 135-136, tak również trybunał arbitrażowy sprawie Aguas del Tunari SA przeciwko Boliwii, który uznał, że oświadczenie rządu holenderskiego na forum parlamentu nie może być postrzegane jako element porozumienia co do interpretacji, ponieważ brak intencji Królestwa Niderlandów, aby miało ono taki skutek, ARB/02/3, wyrok dot. jurysdykcji z 21 października 2005 r., § 249-252; podobnie w zakresie znaczenia intencji trybunał w sprawie HICEE B.V. przeciwko Stowacji, no. 2009-11, wyrok z 23 maja 2011 r., § 134.

${ }^{30}$ Draft Articles on the Law of Treaties with commentaries 1966, Yearbook of the International Law Commission 1966, vol. 2: 221-222. Podobnie KPM w pracach dotyczących zastrzeżeń stwierdziła, że „Intepretacja stanowiąca rezultat deklaracji interpretacyjnej stworzonej w odniesieniu do traktatu dwustronnego przez państwo lub organizację międzynarodową stronę traktatu i zaakceptowana przez inną stronę stanowi autentyczną interpretację traktatu", Guide to Practice on Reservations to Treaties, wytyczna 1.6.3 (tłum. Ł.K.). W polskiej doktrynie na ten temat zobacz: Ehrlich (1957): 62-63; Wyrozumska (2006): 348-350; Kozłowski (2002): 14 - niemniej należy zaznaczyć, że autor koncentruje swoje rozważania na art. 31 ust. 2 KWPT (vide s. 6).

${ }^{31}$ Sprawa Ambatielos - zastrzeżenia wstępne, ICJ Rep. 1952, § 43 i 75 (tłum. Ł.K.). Szczególne znaczenie późniejszych porozumień dla interpretacji traktatu potwierdził również MTS w sprawie wysp Kasikili/Sedudu, Botswana przeciwko Namibii, ICJ Rep 1999, § 49.

${ }^{32}$ Raport KPM 2018: 75 (tłum. Ł.K.). 
nie wymaga żadnej szczególnej formy. Wystarczające jest, aby strony traktatu przez takie późniejsze porozumienie przyjęły pewien sposób rozumienia traktatu. Według KPM, mimo że takie rozumienie samo w sobie nie musi być wiążące, może ono jako środek interpretacji wywołać skutki prawne jako część procesu interpretacji ${ }^{33}$. Niemniej co istotne, Komisja nie przedstawiła żadnego przykładu, kiedy w sytuacji późniejszego porozumienia stron inne środki interpretacji przesądziły o odmiennym zakresie wykładni niż wynikającej z takiego porozumienia. W tym zakresie wydaje się zatem, że bardziej trafne stanowisko sformułowała KPM w pracach dotyczących zastrzeżen, gdzie w komentarzu do wytycznej 1.6.3 zauważyła, że „w przypadku traktatu dwustronnego ta władza należy do obu stron. Zatem jeżeli uzgodnią one interpretację, ta interpretacja przeważa [...]" 34 .

Odnosząc się do skutków prawnych deklaracji interpretacyjnych, warto w pierwszej kolejności odnotować przyjęta przez KPM konkluzję 7 ust. 1, która stanowi, że: „Późniejsze porozumienia [...] na podstawie art 31 ust. 3 przyczyniają się, w interakcji w innymi środkami interpretacji, do wyjaśnienia znaczenia traktatu. To może skutkować zawężeniem, poszerzeniem lub w inny sposób ustaleniem zakresu potencjalnej interpretacji, uwzględniając jakikolwiek zakres dla działań dyskrecjonalnych, które traktat przyznaje jego stronom".

W komentarzu do tego przepisu Komisja uznaje między innymi możliwość odejścia przez strony w drodze późniejszego porozumienia od zwykłego znaczenia wyrazów traktatu i nadania im specjalnego znaczenia w rozumieniu art. 31 ust. $4 \mathrm{KWPT}^{35}$. Odejście od zwykłego znaczenia wyrazów może być szczególnie uzasadnione, jeżeli uzna się, że strony, zawierając traktat, celowo przez użycie ogólnych sformułowań chciały nadać im znaczenie lub treść ulegajaca ewolucji, tak aby uwzględnić rozwój prawa międzynarodowego ${ }^{36}$. Ponadto należy pamiętać, że późniejsze porozumienia moga przyczynić się do wyjaśnienia przedmiotu i celu traktatu ${ }^{37}$.

\section{Interpretacja a zmiana traktatu}

Rozgraniczenie możliwego zakresu interpretacji traktatu przez późniejsze porozumienia od jego zmiany ${ }^{38}$ stanowi przedmiot ożywionej debaty zarówno w międzynarodowym orzecznictwie, jak i w poglądach doktryny ${ }^{39}$. Dość powiedzieć, że już jeden z najbardziej znanych przykładów późniejszego porozumienia $\mathrm{w}$ międzynarodowym prawie inwestycyjnym - nota interpretacyjna Ko-

33 Raport KPM 2018: 77-78.

${ }^{34}$ Guide to Practice on Reservations to Treaties: 117 (tłum. Ł.K.).

${ }^{35}$ Guide to Practice on Reservations to Treaties: 50-51. Art. 31 ust. 4 KWPT stanowi: „Specjalne znaczenie należy przypisywać wyrazowi wówczas, gdy ustalono, że taki był zamiar stron”.

${ }^{36}$ Tak MTS w sprawie sporu dotyczącego praw żeglugowych i innych, Kostaryka przeciwko Nikaragui, ICJ Rep. 2009, § 64.

${ }^{37}$ Gardiner (2015): 212-215 oraz cyt. tam orzecznictwo MTS potwierdzajace to stanowisko.

$38 \mathrm{Na}$ gruncie KWPT zmiana traktatu jest regulowana art. 39-41.

39 Aust (2013): 212-214. 
misji ds. Wolnego Handlu Północnoamerykańskiego Układu Wolnego Handlu (dalej: Porozumienie NAFTA) zawężająca wykładnię art. 1105 Porozumienia NAFTA $^{40}$ spotkała się z zarzutem wykroczenia poza zakres dopuszczalnej interpretacji. W szczególności trybunał arbitrażowy w sprawie Pope \& Talbot przeciwko Kanadzie stwierdził, że jeżeli „miałby oceniać, czy działanie Komisji stanowi interpretację czy poprawkę, wybrałby to ostatnie"41. Skład orzekający uznał jednak, że ta kwestia nie jest istotna, ponieważ bez względu na kwalifikację prawną noty jego wcześniejsze rozstrzygnięcia w tej samej sprawie były z nią zgodne ${ }^{42}$. Takie podejście potwierdził między innymi trybunał arbitrażowy w sprawie ADF, stwierdzając w odniesieniu do noty interpretacyjnej: „żadne bardziej autentyczne ani autorytatywne źródło instrukcji w zakresie tego, co strony zamierzały odzwierciedlić w konkretnych postanowieniach Porozumienia NAFTA, nie jest możliwe. Nic w Porozumieniu NAFTA nie pozwala na sugestię, że trybunał działający na podstawie rozdziału 11 może określać dla siebie, czy dokument przedstawiony mu jako interpretacja stron działających za pośrednictwem Komisji ds. Wolnego Handlu jest w rzeczywistości poprawka, która przypuszczalnie mogłaby być zlekceważona, zanim nie zostanie ratyfikowana przez wszystkie strony, zgodnie z ich odpowiednim prawem wewnętrznym" 4 .

Sformułowana w tym zakresie przez KPM konkluzja 7 ust. 3 stanowi: „Domniemywa się, że strony traktatu przez porozumienie lub praktykę maja na celu interpretację traktatu, a nie jego poprawianie lub modyfikowanie. Możliwość wprowadzania poprawek lub dokonywania zmiany traktatu przez późniejszą praktykę stron nie została powszechnie uznana [...]”. Znaczacy $\mathrm{w}$ tym postanowieniu jest fakt, że podczas gdy zdanie pierwsze odnosi się zarówno do porozumien, jak i praktyki, to już zdanie drugie odwołuje się jedynie do praktyki. Tym samym Komisja przyznaje, że strony traktatu posiadaja dużą swobodę w zakresie interpretacji traktatu w drodze późniejszych porozumień, uznając, że ich zakres „może nawet iść dalej niż zwykłe znaczenie wyrazów traktatu" ${ }^{44}$. Co więcej, wykładnia ta może uwzględniać również bieżące dla momentu interpretacji uwarunkowania, w których traktat funkcjonuje. W rezultacie trafnie zdaje się wskazywać Ian Sinclair, że rozgraniczenie interpretacji od modyfikacji może niekiedy być „trudne, jeżeli nie niemożliwe do ustalenia" ${ }^{45}$.

${ }^{40}$ Nota dostępna na: <http://www.sice.oas.org/tpd/nafta/commission/ch11understanding_e. asp>.

${ }^{41}$ Wyrok w sprawie szkód z 31 maja 2002 r., <www.italaw.com>, § 43 (tłum. Ł.K.).

${ }^{42}$ Wyrok w sprawie szkód z 31 maja 2002 r., § 56-64.

${ }^{43}$ ADF Group Inc przeciwko Stanom Zjednoczonym, no ARB(AF)/00/1, wyrok z 9 stycznia 2003 r., $\$ 177$ (tłum. Ł.K.). Podobnie trybunały arbitrażowe w sprawach Waste Management Inc przeciwko Meksykowi, no ARB(AF)/00/3, wyrok z 30 kwietnia 2004 r., § 91-93, oraz Glamis Gold Ltd przeciwko Stanom Zjednoczonym, wyrok z 8 sierpnia 2009 r., § 559.

${ }^{44}$ Raport KPM 2018: 58 (tłum. Ł.K.); podobnie za szerokim rozumieniem kompetencji państw w tym zakresie Villiger (2009): 429, oraz Jennings, Watts (1992): 630.

${ }^{45}$ Sinclair (1984): 138. 


\section{Rozróżnienie deklaracji interpretacyjnych przewidzianych i nieprzewidzianych traktatem}

Możliwość przyjęcia późniejszego porozumienia dotyczącego interpretacji wyraźnie przewiduje szereg traktatów dotyczących problematyki ochrony inwestycji zagranicznych ${ }^{46}$. Jednym z pierwszych w tym zakresie było Porozumienie NAFTA, którego art. 1131 ust. 1 stanowi, że: „Interpretacja postanowień tego Porozumienia sformułowana przez Komisję będzie wiążąca dla trybunału ustanowionego na podstawie tej Sekcji”. Podobna formuła znalazła się w kanadyjskim i amerykańskim modelu umowy inwestycyjnej z 2004 r. Ten ostatni w art. 30 ust. 3 określał, że „Wspólna decyzja stron [...] określająca interpretację postanowień tego Traktatu będzie wiążąca dla trybunału [...]"47.

Takie rozwiązanie przyjęła również Unia Europejska. W pierwszej umowie z Kanadą (2016) zawierającej rozdział dotyczący ochrony inwestycji zagranicznych, w art. 8.31 ust. 3 stwierdza się: „W przypadku pojawienia się poważnych wątpliwości dotyczących wykładni, która może mieć wpływ na inwestycję, Komitet ds. Usług i Inwestycji może zalecić, zgodnie z art. 8.44 ust. 3 lit. a), by Wspólny Komitet CETA przyjął wykładnię niniejszej umowy. Wykładnia przyjęta przez Wspólny Komitet CETA jest wiażaca dla Trybunału ustanowionego na podstawie niniejszej sekcji. Wspólny Komitet CETA może zdecydować, że wykładnia ma moc wiążąca od określonej daty"48.

Wyjątkowo innowacyjne rozwiązanie w zakresie interpretacji i stosowania traktatu przewiduje Porozumienie ustanawiające strefę wolnego handlu pomiędzy Australia a ChRL z 17 czerwca 2015 r. (ChAFTA). Artykuł 9.11 ust. 4 ChAFTA określa, że niedyskryminacyjne środki wprowadzone przez jedna stronę dla uzasadnionych celów publicznych nie mogą być przedmiotem skargi inwestora. Jeżeli inwestor wnosi skargę na środki regulacyjne strony, postępowanie arbitrażowe może być zawieszone w celu zapewnienia czasu na konsultacje państw stron. Jeżeli przyjmą one stanowisko, że zaskarżone środki mieszczą się we wskazanym wyżej wyłączeniu, decyzja ta zgodnie z art. 9.18 ust. 3 ChAFTA jest wiążąca dla trybunału rozstrzygającego spór. W rezultacie zatem strony porozumienia pozostawiły sobie wyjątkowa $\mathrm{w}$ dotychczasowej praktyce traktatowej możliwość interpretacji jego art. 9.11 ust. 4 ChAFTA, tak aby zagwarantować, że w przypadku ich konsensusu przepis ten nie będzie odmiennie od intencji stron interpretowany przez trybunały arbitrażowe.

Brak wyraźnego przepisu traktatowego określającego kompetencje jego stron do przyjmowania interpretacji traktatu nie oznacza oczywiście, że pań-

${ }^{46}$ Przykłady takich traktatów - zob. szerzej Gaukrodger (2016); UNCTAD, Interpretation of IIAs: What states can do, IIA Issues Note no. 3, December 2011, <https://unctad.org/en/pages/publications/Intl-Investment-Agreements---Issues-Note.aspx>; Methymaki, Tzanakopoulos (2017): $161-164$.

${ }^{47}$ Zob. <https://www.state.gov/documents/organization/117601.pdf>, przepis ten został powtórzony w amerykańskiej umowie inwestycyjnej z 2012 r.: <https:/www.state.gov/documents/ organization/188371.pdf>.

48 Dz. Urz. UE L 11 z 14 stycznia 2017 r.: 23-1079. 
stwa nie mogą zawierać porozumień dotyczacych jego interpretacji (np. w formie deklaracji interpretacyjnych). Jak wskazano wcześniej, kompetencja ta wynika z powszechnego prawa międzynarodowego i dlatego nie wymaga dodatkowej regulacji dla jej zastosowania. Podstawowa różnica pomiędzy skutkami prawnymi tych interpretacji wiąże się z faktem, że traktaty, jak te przedstawione powyżej, w sposób bardziej jednoznaczny określają ich skutek prawny. Podczas gdy deklaracja państw stron ma być wzięta pod uwagę, noty interpretacyjne przewidziane konkretnym traktatem posiadaja zazwyczaj, zgodnie z jego postanowieniami, moc bezwzględnie wiążącą. Jak wskazano jednak wcześniej w odniesieniu do znaczenia prawnego późniejszych porozumień interpretacyjnych, rozróżnienie na deklaracje przewidziane i nieprzewidziane traktatem może nie mieć w praktyce tak istotnego znaczenia.

\section{DEKLARACJE INTERPRETACYJNE DO UMÓW INWESTYCYJNYCH}

Zasadność większej proaktywności państw w zakresie wykładni traktatów inwestycyjnych przez deklaracje interpretacyjne podkreśla coraz więcej państw i organizacji międzynarodowych ${ }^{49}$. Według UNCTAD: „Autorytatywne, wspólne interpretacje stron oferuja zatem poziom bardzo potrzebnej jasności dla inwestorów, państwa przyjmujaccego, jak również dla arbitrów. To narzędzie reformy jest potencjalnie najłatwiejsze w praktycznym zastosowaniu, ponieważ pozwala stronom traktatu przedstawić swoje stanowisko w zakresie konkretnej klauzuli międzynarodowej umowy inwestycyjnej bez podejmowania procedury porównawczo droższej i bardziej czasochłonnej polegajacej na modyfikacji lub renegocjacji traktatu (deklaracje interpretacyjne nie wymagają ratyfikacji)" ${ }_{50}$.

Zdaniem Anathei Roberts konieczna jest modyfikacja dotychczasowej nierównowagi władzy interpretacyjnej w odniesieniu do dwustronnych umów inwestycyjnych (ang. bilateral investment treaty, BIT), która to władza w nazbyt dużym stopniu została powierzona trybunałom arbitrażowym ${ }^{51}$. Jest to tym bardziej pożądane, jeśli wziąć pod uwagę jego dotychczasowe niewielkie stosowanie zarówno przez państwa, jak i w rezultacie przez trybunały arbitra$\dot{z}_{\text {owe }}{ }^{52}$. Dotychczasowe doświadczenia w tym zakresie obejmują przedstawioną już notę interpretacyjną Komisji NAFTA z 2001 r. oraz przede wszystkim praktykę Indii, które, jak się wydaje, są jak dotąd jedynym państwem systemowo popierającym zawieranie takich deklaracji. W styczniu 2016 r. Rząd

${ }^{49}$ W latach 2017-2018 w ramach prac Grupy Roboczej III UNCITRAL, zajmującej się reformą systemu rozwiązywania sporów „inwestor przeciwko państwu”, na znaczenie tej problematyki wskazywały m.in. Kanada, Tajlandia, Stany Zjednoczone, Wietnam oraz Unia Europejska, informacja na: <https://www.ejiltalk.org/uncitral-and-isds-reforms-what-are-states-concerns/>.

50 UNCTAD, World Investment Report 2017: 132-133 (tłum. Ł.K.).

51 Roberts (2010): 179-180. Zob. również Gordon, Pohl (2015); podobnie Ewing-Chow, Losari (2015): 114 .

52 Weeramantry (2012): 210; Nolte (2013): 237; podobną konkluzję można wywieść z artykułu Christophera Schreura dotyczącego metod interpretacji przez trybunału arbitrażowe, w którym problematyka stosowania art. 31 ust. 3 lit. a) zasadniczo nie istnieje - Schreuer (2010): 129-151. 
Indii przyją projekt wspólnego interpretacyjnego oświadczenia, które zostało zaproponowane grupie 25 państw (bez Polski) ${ }^{53}$. Tak duża liczba państw, którym przedstawiono identyczny projekt porozumienia interpretacyjnego odpowiedniego traktatu dwustronnego, jest nieco zaskakująca i zdaje się opierać na założeniu, że te 25 umów, których nota ma dotyczyć, ma identyczna treść. Projekt indyjskiej noty jest stosunkowo obszerny i obejmuje obowiązek przyznania szerokiego marginesu swobody państwom w realizacji ich polityki, definicji inwestora i inwestycji, wyłączenia środków podatkowych, rozumieniu traktowania sprawiedliwego i słusznego oraz pełnej ochronie i bezpieczeństwie, klauzuli ramowej, traktowania narodowego, klauzuli najwyższego uprzywilejowania, wywłaszczenia, kwestii istotnych interesów bezpieczeństwa oraz mechanizmu rozwiązywania sporów inwestor-państwo. Noty tego rodzaju Indie zdołały zawrzeć już z Bangladeszem (4.10.2017) ${ }^{54}$ oraz z Kolumbią $(4.10 .2018)^{55}$. To ostatnie państwo wydaje się również popierać tego rodzaju praktykę. W październiku 2017 r. zawarło bowiem wspólną deklarację interpretacyjna z Francją (w zakresie pojęcia „obowiązki wynikające z prawa międzynarodowego") oraz z Kanada (w odniesieniu do prawa do regulacji, pełnej ochrony i bezpieczeństwa oraz minimalnego standardu traktowania) w tym ostatnim przypadku za pośrednictwem wspólnej komisji działającej na podstawie Porozumienia ustanawiajacego strefę wolnego handlu z Kanada ${ }^{56}$.

Warto również odnotować wspólny instrument interpretacyjny dotyczący umowy CETA. Stanowi on porozumienie towarzyszące zawarciu traktatu, a nie późniejsze porozumienie, niemniej KWPT zasadniczo nie różnicuje skutków prawnych tych porozumień. Dokument ten w zakresie inwestycji zagranicznych potwierdza prawo stron do regulacji oraz wskazuje, że umowa CETA stanowi ,istotną i radykalna zmianę zasad inwestycyjnych i zasad rozstrzygania sporów" $(\S 6)^{57}$. Instrument wbrew nazwie, przynajmniej w zakresie ochrony inwestycji, stanowi raczej formę uzasadnienia aniżeli interpretacji umowy CETA. Jego postanowienia bowiem w znacznym stopniu powtarzają to, co jest już w umowie, skądinąd stosunkowo precyzyjnej w odróżnieniu od większości traktatów inwestycyjnych. Wspólny instrument negocjacyjny jest praktycznym potwierdzeniem stanowiska Unii Europejskiej, że „konieczne jest, aby zapewnić, że strony umów dwustronnych zachowają kontrolę nad interpretacja swoich umów przez posiadanie możliwości przyjęcia wiążącej interpretacji”58.

${ }^{53}$ Zob. <http://indiainbusiness.nic.in/newdesign/upload/Consolidated_Interpretive-Statement. pdf>. Republika Indii wypowiedziała umowę między Rządem Rzeczypospolitej Polskiej a Rządem Republiki Indii o popieraniu i ochronie inwestycji, sporządzoną w Warszawie 7 października 1996 r., co zostało notyfikowane Rzeczypospolitej Polskiej 4 maja 2016 r. Zgodnie z art. 15 ust. 1 umowy utraciła ona moc obowiązująca 4 maja 2017 r., Dz. U. 2017, poz. 604.

${ }^{54}$ Zob. <https://dea.gov.in/sites/default/files/Signed\%20Copy\%20of\%20JIN.pdf>.

${ }^{55}$ Zob. <https://mea.gov.in/Portal/LegalTreatiesDoc/CO18B3453.pdf>.

${ }^{56} \mathrm{UNCTAD}$, Recent developments in the international investment regime, IIA Issues Note 2018, no 1: 6 .

${ }^{57}$ Dz. Urz. UE L 11 z 14 stycznia 2017 r.

${ }^{58}$ Possible reform of investor-State dispute settlement (ISDS) - Submission from the European Union and its Member States, 24.1.2019, UNCTAD Working Group III (Investor-State Dispute Settlement Reform), Thirty-seventh session New York, 1-5 April 2019, pkt 26 (tłum. Ł.K.). 
Kwestią kontrowersyjna jest, jaki powinien być skutek temporalny przyjętej interpretacji w odniesieniu do stron trzecich, w szczególności inwestorów. Według Roberts, jeżeli przyjęta wykładnia jest nierozsądna i stanowi de facto modyfikację, należy domniemywać jedynie prospektywnych skutków prawnych takiej interpretacji ${ }^{59}$.

Biorac pod uwage fakt, że Polska zakończyła obowiązywanie lub jest w trakcie procesu zakończenia obowiązywania umów inwestycyjnych z państwami $\mathrm{UE}^{60}$, ewentualna decyzja o zawieraniu deklaracji interpretacyjnych powinna odnosić się przede wszystkim do państw pozaunijnych, z którymi zawarte umowy generują największą ilość roszczeń. Do tych państw należałoby zaliczyć przede wszystkim Stany Zjednoczone, Szwajcarię ${ }^{61}$ i Australię ${ }^{62}$.

\section{POTENCJALNA TREŚĆ DEKLARACJI INTERPRETACYJNYCH POLSKI DO UMÓW INWESTYCYJNYCH Z PAŃSTWAMI TRZECIMI}

Majacc na względzie indywidualny kontekst interpretacyjny poszczególnych umów inwestycyjnych, bez wątpienia treść konkretnej deklaracji powinna być sprofilowana każdorazowo w odniesieniu do danego traktatu. Niemniej jednak, dostrzegając podobieństwo umów inwestycyjnych oraz zachowując pewien poziom ogólności rozważań, można wskazać na pewne elementy, które powinny się znaleźć w dwustronnej deklaracji interpretacyjnej Polski z wyżej wspomnianymi państwami. Należą do nich:

1) prawo do regulacji - kontrowersje dotyczace ingerowania w to kluczowe uprawnienie państw na skutek bardzo szeroko rozumianych standardów inwestycyjnych przez trybunały arbitrażowe powoduje, że kwestia ta bez wątpienia wymaga wyjaśnienia. Inspiracjac w tym zakresie mogłyby być mające deklaratoryjny charakter postanowienia umowy o ochronie inwestycji między Unią Europejską i jej państwami członkowskimi a Republika Singapuru z 19 października 2018 r.: „Strony potwierdzają przysługujące

59 Roberts (2010): 207-215; o problemach temporalnych zasadniczych zmian wykładni sądów zob. Supera (2013).

60 „RP, z uwagi na prawo UE, rozwiązuje umowy intra-EU BIT za porozumiem stron, łącznie z klauzulą przedłużonego obowiązywania umowy, co dotyczy umów z Dania, Estonia, Republiką Czeska, Rumunią i Łotwą (prowadzone są też konsultacje robocze w tej sprawie ze Słowacja). $\mathrm{RP}$ wypowiedziała również, z uwagi na prawo UE, umowy intra-EU BIT zawarte z Belgią i Luksemburgiem, Cyprem, Francja, Holandia, Portugalia, Austria, Szwecja, Niemcami, Hiszpania, Finlandia, Bułgaria, Grecja, Chorwacja, Litwa, Węgrami i Wielką Brytanią,, zob. uzasadnienie Projektu ustawy - o wypowiedzeniu umowy między Rzeczapospolitą Polską a Republiką Słowenii o wzajemnym popieraniu i ochronie inwestycji, sporządzonej w Lublanie dnia 28 czerwca 1996 r., druk sejmowy nr 3164 z 23 stycznia 2019 r.: 1.

${ }^{61}$ Te dwa państwa znajdują się w pierwszej 10 państw, z których pochodzą roszczenia inwestycyjne, zob. IIA Issues Note, Investor-state dispute settlement: review of developments in 2017: 3 .

62 Według doniesień medialnych, na podstawie umowy z Australia, przeciwko RP wytoczono jedno z największych roszczeń inwestycyjnych, zob. Australijczycy stracili cierpliwość. Żądają miliardów, Dziennik Gazeta Prawna z 11 lutego 2019 r.: A7. 
im prawo do wprowadzania regulacji na swoim terytorium w celu osiagania uzasadnionych celów polityki, takich jak ochrona zdrowia publicznego, usług społecznych, edukacji publicznej, bezpieczeństwa, środowiska lub moralności publicznej, ochrona socjalna lub ochrona konsumenta, ochrona danych i ochrona prywatności oraz promowanie i ochrona różnorodności kulturowej” (art. 2 ust. 1) $)^{63}$;

2) klauzula najwyższego uprzywilejowania - klauzula ta jest przedmiotem zróżnicowanych interpretacji trybunałów arbitrażowych, z których część uznaje możliwość jej stosowania do przepisów dotyczących rozwiązywania sporów, niekiedy nawet z naruszeniem kluczowej dla tej normy zasady eiusdem generis ${ }^{64}$. Deklaracja interpretacyjna powinna zatem wskazywać w tym zakresie, że klauzula najwyższego uprzywilejowania nie ma zastosowania do mechanizmu rozwiąywania sporów zgodnie doktryną braku obowiązkowej jurysdykcji sądów w prawie międzynarodowym oraz że nie może przyznawać możliwości przywoływania praw i obowiązków, których zakres wykracza poza to, co określone w konkretnej umowie ${ }^{65}$;

3) wymóg upływu czasu na konsultacje poprzedzający przekazanie sporu do trybunału arbitrażowego - z uwagi na fakt, że trybunały arbitrażowe niekiedy interpretują bardzo elastycznie ten wymóg (wskazując, że bez względu na upływ czasu wystarczy wykazanie, iż negocjacje inwestor-państwo nie zakończyły się powodzeniem), zasadne jest wskazanie w deklaracji interpretacyjnej, że postanowienia $\mathrm{w}$ tym zakresie nie maja charakteru aspiracyjnego, ale są bezwzględną przesłanką proceduralną ${ }^{66}$;

4) traktowanie sprawiedliwe i słuszne - najczęściej powoływane roszczenie w międzynarodowym arbitrażu inwestycyjnym, a przez swoją niedookreśloność najtrudniejsze do obrony z perspektywy państwa ${ }^{67}$. Strony traktatu moga zatem wskazać, że ich celem było rozumienie standardu traktowania sprawiedliwego i słusznego jako obejmującego elementy międzynarodowego prawa zwyczajowego, takie jak zakaz odmowy ochrony prawnej w postępowaniu karnym, cywilnym lub administracyjnym, rażące naruszenie zasad spra-

${ }^{63}$ Tekst umowy w języku polskim na: <https://data.consilium.europa.eu/doc/document/ST7980-2018-INIT/pl/pdf>.

${ }^{64}$ Zob. aneks do raportu KPM 2015, A/70/10 dotyczący interpretacji klauzuli najwyższego uprzywilejowania w międzynarodowym arbitrażu inwestycyjnym; zob. również Kałduński (2014): 153-154.

${ }^{65}$ Podobnie również trybunał w sprawie Hochtief przeciwko Argentynie $§ 81$ oraz Autobuses Urbanos del Sur S.A., Teinver S.A. and Transportes de Cercanías S.A. przeciwko Argentynie, no. ARB/09/1, wyrok z 21 lipca 2017 r., § 880, 884. Zasadność deklaracji interpretacyjnej w odniesieniu do KNU potwierdza dodatkowo fakt, że same komitety uchylające ICSID potwierdzaja, że zawiera ona postanowienia podatne na różne kierunki wykładni, zob. Suez, Sociedad General de Aguas de Barcelona, S.A. and Vivendi Universal, S.A. przeciwko Argentynie, no. ARB/03/19, decyzja w sprawie uchylenia wyroku z 5 maja 2017 r., § 133 oraz 252-253; Daimler Financial Services AG przeciwko Argentynie, no. ARB/05/1, decyzja w sprawie uchylenia wyroku z 7 stycznia 2015 r., $\$ 187$.

${ }_{66}$ Zob. szerzej Ganesh (2017); Alps Finance and Trade AG przeciwko Stowacji, wyrok z 5 marca 2011 r., § 20.

${ }^{67}$ Szerzej zob. Kułaga (2016a): 13-23. 
wiedliwości proceduralnej, oczywista arbitralność czy ukierunkowana dyskryminacja z uwagi na oczywiście bezprawne kryteria;

5) pełna ochrona i bezpieczeństwo - z uwagi na fakt, że trybunały arbitrażowe niekiedy interpretują ten standard ponad to, co wynika z międzynarodowego prawa zwyczajowego, strony traktatu mogłyby wyjaśnić, że ich celem było rozumienie tego standardu jako dotyczącego bezpieczeństwa fizycznego inwestorów i inwestycji68;

6) klauzula ramowa - podobnie jak w przypadku klauzuli najwyższego uprzywilejowania, orzecznictwo arbitrażowe dotyczace klauzuli ramowej jest bardzo dalekie od spójności. W tym kontekście strony traktatu mogłyby wyjaśnić, że klauzula ta nie może być rozumiana jako sprzeczna z powszechnie akceptowaną zasadą prawa międzynarodowego, że naruszenie kontraktu zawartego przez państwo z inwestorem innego państwa nie jest per se naruszeniem prawa międzynarodowego ${ }^{69}$.

Przedstawione wyżej wyliczenie podstawowych problemów interpretacyjnych na podstawie umów inwestycyjnych starego typu (tj. zawieranych najczęściej przed 2004 r.), czyli wszystkich traktatów, których stroną jest RP, nie jest wyczerpujace. Daje ono jednak pewien obraz zagadnień, które powinny być przedmiotem deklaracji, aczkolwiek można rozważać również inne elementy ${ }^{70}$.

\section{ZAKOŃCZENIE}

„Często zapomina się, że strony traktatu, to jest państwa, które są nim związane, sa równocześnie właścicielami traktatu. To jest ich traktat [...] prawo międzynarodowe mówi, że strony traktatu [...] mogą go interpretować"71. Teza ta - z jednej strony oczywista - okazuje się, że w praktyce bardzo rzadko jest wykorzystywana przez państwa. Niewątpliwie istotnym mankamentem w kontekście wspólnych deklaracji interpretacyjnych może być trudność w osiagnięciu porozumienia z drugą stroną co do wykładni traktatu. Częściej jednak wydaje się, że problemem jest raczej brak podjęcia starań zmierzajacych do osiagnięcia wspólnego rozumienia traktatu oraz brak wystarczajacej świadomości, że traktat zawierający arbitrażową czy sądową klauzulę rozwią-

68 Kułaga (2016a): 335-339.

69 Zob. szerzej na ten temat sprawa Societé Générale de Surveillance S.A przeciwko Pakistanowi, decyzja w sprawie jurysdykcji z 9 września 2003 r., ARB/01/13, § 167; Świątkowski (2009): 17-109.

${ }^{70}$ Przykładowo określenie, jakimi cechami powinny się charakteryzować inwestycje objęte ochroną traktatową (np. czas trwania, zaangażowanie kapitału lub innych zasobów, oczekiwanie zysków lub korzyści, założenie ryzyka oraz wkład w rozwój państwa przyjmującego), czy wskazanie, jak strony rozumieją postanowienia dotyczące zakazu wywłaszczenia pośredniego (regulacyjne działania państwa o charakterze niedyskryminacyjnym, które mają na celu i sa stosowane do ochrony uzasadnionych celów dobra publicznego, nie stanowią pośredniego wywłaszczenia, poza wyjątkowymi okolicznościami).

${ }^{71}$ Crawford (2013): 31 (tłum. Ł.K.). 
zywania sporów nie zostaje przekazany na wyłączność interpretacyjną sądów międzynarodowych, ale jego sposób rozumienia w praktyce międzynarodowej może i powinien być przedmiotem nieustannej czujności jego „właścicieli”72. Dlatego można tylko rekomendować zaangażowanie się również Polski w tego rodzaju praktykę w odniesieniu do umów inwestycyjnych z kluczowymi państwami spoza UE.

\author{
Łukasz Kułaga \\ Uniwersytet Kardynała Stefana Wyszyńskiego w Warszawie \\ l.kulaga@uksw.edu.pl \\ https://orcid.org/0000-0003-0784-8293
}

Alvarez, J.E., Brink, T. (2010). Revisiting the necessity defense: Continental Casualty v. Argentina. Institute for International Law and Justice Working Paper, no. 3.

Aust, A. (2013). Modern Treaty Law and Practice. Cambridge.

Balcerzak, M. (2008). Zagadnienie precedensu w międzynarodowym prawie praw człowieka. Toruń.

Burek, W. (2012). Zastrzeżenia do traktatów z dziedziny ochrony praw człowieka. Warszawa.

Cameron, I. (2006). Treaties, declarations of interpretation, [w:] Max Planck Encyclopedia of Public International Law. [Online: <https://opil.ouplaw.com/home/MPIL>].

Cheng, T.-H. (2009). Precedent and control in investment treaty arbitration, [w:] A. Bjorklund, I. Laird, S. Ripinsky (eds.), Investment Treaty Law: Current Issues III, London: 147-180.

Cho, S., Kurtz, J. (2018). Convergence and divergence in international economic law and politics. European Journal of International Law 29(1): 169-203.

Crawford, J. (2013). Subsequent agreements and practice from a consensualist perspective, [w:] G. Nolte (ed.), Treaties and Subsequent Practice. Oxford: 29-33.

Dorr, O., Schmalenbach, K. (2012). Vienna Convention on the Law of Treaties: A Commentary. Berlin-Heidelberg.

Ehrlich, L. (1957). Interpretacja traktatów. Warszawa.

Ewing-Chow. M., Losari, J.J. (2015). Which is to be the master? Extra-arbitral interpretative procedures for IIAs, [w:] J.E. Kalicki, A. Joubin-Bret (eds.), Reshaping the Investor-State Dispute Settlement System. Leiden-Boston: 91-114.

Fauchald, O.K. (2008). The legal reasoning of ICSID tribunals - an empirical analysis. European Journal of International Law 19(2): 301-364.

Ganesh, A. (2017). Cooling off period (investment arbitration). Max Planck Institute Luxembourg for International, European and Regulatory Procedural Law Working Paper Series.

Gardiner, R. (2015). Treaty Interpretation. Oxford.

Gaukrodger, D. (2016). The legal framework applicable to joint interpretive agreements of investment treaties. OECD Working Papers on International Investment no. 1.

Gordon, K., Pohl, J. (2015). Investment treaties over time - treaty practice and interpretation in a changing world. OECD Working Papers on International Investment no. 2.

Ishikawa, T. (2014). Keeping interpretation in investment treaty arbitration 'on track': the role of states parties. Transnational Dispute Management 11(1): 1-33.

Jennings, R.Y., Watts, A. (1992). Oppenheim's International Law. Oxford.

Kałduński, M. (2014). Klauzula największego uprzywilejowania, [w:] J. Symonides, D. Pyć (red.), Wielka encyklopedia prawa. Tom 4: Prawo międzynarodowe publiczne. Warszawa: 153-154.

Kaufmann-Kohler, G. (2007). Arbitral precedent: dream, necessity or excuse? Arbitration International 23(3): 257-378.

${ }^{72}$ Jak wskazała Wyrozumska ([2017]: 71): „Istotny w tym względzie jest również element dynamiczny - weryfikowanie decyzji sądów międzynarodowych w drodze kontroli politycznej, społecznej [...]". 
Kill, T. (2008). Don't cross the streams: past and present overstatement of customary international law in connection with conventional fair and equitable treatment obligations. Michigan Law Review 106(5): 854-880.

Kozłowski, A. (2002). Interpretacja traktatu międzynarodowego w świetle jego kontekstu. Warszawa.

Krzan, B. (2009). Praktyczne znaczenie zakazu składania zastrzeżeń (uwagi na tle deklaracji interpretacyjnych do Statutu Rzymskiego), [w:] Z. Galicki, T. Kamiński, K. Myszona-Kostrzewa (red.), 40 lat minęło - Praktyka i perspektywy Konwencji wiedeńskiej o prawie traktatów. Warszawa: 321-331.

Krzan, B. (2015). Sądowe stosowanie prawa międzynarodowego w świetle roli państw w administrowaniu „sprawiedliwością międzynarodowa” - system czy chaos? [w:] R. Kwiecień (red.), Państwo a prawo międzynarodowe jako system prawa. Lublin: 205-318.

Kułaga, Ł. (2014). Międzynarodowy arbitraż inwestycyjny z perspektywy zasady rządów prawa, [w:] C. Mik (red.), Arbitraż w prawie międzynarodowym. Warszawa: 202-220.

Kułaga, Ł. (2016a). Minimalny standard traktowania a traktowanie sprawiedliwe i słuszne w międzynarodowym prawie inwestycyjnym. Warszawa.

Kułaga, Ł. (2016b). W kierunku zmiany paradygmatu międzynarodowych porozumień inwestycyjnych. Forum Prawnicze 5(37): 31-46.

Kułaga, Ł. (2018). Udział Polski w transformacji międzynarodowego prawa inwestycyjnego. Aspekty prawnomiędzynarodowe i konstytucyjne. Przegląd Sejmowy 3(146): 107-111.

Linderfalk, U. (2007). On the Interpretation of Treaties - The Modern International Law as Expressed in the 1969 Vienna Convention on the Law of Treaties. Springer.

Methymaki, E., Tzanakopoulos, A. (2017). Masters of puppets? Reassertion of control through joint investment treaty interpretation, [w:] A. Kulick (ed.), Reassertion of Control over the Investment Treaty Regime. Cambridge: $155-180$.

Morawski, L. (2005). Główne problemy współczesnej filozofii prawa. Warszawa.

Nolte, G. (2013). Reports for the ILC Study Group on Treaties over Time. Report 2: Jurisprudence under special regimes relating to subsequent agreements and subsequent practice, [w:] G. Nolte (ed.), Treaties and Subsequent Practice. Oxford: 169-209.

Reinisch, A. (2009). Future of investment arbitration, [w:] C. Binder, U. Kriebaum, A. Reinisch, S. Wittich (eds.), International Investment Law for the 21st Century - Essays in Honour of Christoph Schreuer. Oxford: 894-916.

Roberts, A. (2010). Power and persuasion in investment treaty interpretation: the dual role of states. American Journal of International Law 104: 179-225.

Schill, S.W. (2010). International Investment Law and Comparative Public Law - An Introduction, [w:] S.W. Schill (ed.), International Investment Law and Comparative Public Law. Oxford: 3-38.

Schneiderman, D. (2008). Constitutionalizing Economic Globalization. Cambridge.

Schreuer, C. (2010). Diversity and harmonization of treaty interpretation in investment arbitration, [w:] M. Fitzmaurice, O. Elias, P. Merkouris (eds.), Treaty Interpretation and the Vienna Convention on the Law of Treaties: 30 Years on. Leiden: 129-152.

Schreuer, C., Weiniger, M. (2008). A doctrine of precedence? [w:] P. Muchlinski, F. Ortino, C. Schreuer (eds.), The Oxford Handbook of International Investment Law. Oxford: 11881206.

Sinclair, I. (1984). The Vienna Convention on the Law of Treaties. Manchester.

Supera, Ł. (2013). Ochrona uzasadnionych oczekiwań a wsteczne działanie wykładni orzeczniczej w prawie cywilnym. Warszawa.

Świątkowski, M. (2009). Naruszenie przez państwo umowy z inwestorem zagranicznym w świetle traktatów inwestycyjnych. Warszawa.

Villiger, M.E. (2009). Commentary on the 1969 Vienna Convention on the Law of Treaties. Leiden. Weeramantry, R. (2012). Treaty Interpretation in Investment Arbitration. Oxford.

Wyrozumska, A. (2006). Umowy międzynarodowe - teoria i praktyka. Warszawa.

Wyrozumska, A. (2014). Prawotwórcza działalność sądów międzynarodowych i jej granice, [w:] A. Wyrozumska (red.), Granice swobody orzekania sądów międzynarodowych. Łódź: 3-82. 


\section{INTERPRETATIVE DECLARATIONS AS AN INSTRUMENT OF TRANSFORMATION OF INTERNATIONAL INVESTMENT LAW. MEASURES FOR RESTRAINING JUDICIAL ACTIVISM}

\section{Sum mary}

International investment law has been subject to significant criticism for at least a decade, due to the methodology applied in the jurisprudence of arbitration tribunals. As a result, both States and international organizations are seeking measures to limit the judicial activism of these tribunals. The most commonly used mechanisms in this respect include renegotiating existing investment treaties, concluding new agreements and terminating treaties. These mechanisms, which are generally the most desirable and guarantee the greatest certainty in terms of rights and obligations, also have significant shortcomings, above all related to the time required to achieve the desired result. This article postulates that interpretative declarations may be the most optimal solution for limiting judicial activism in international investment law. Although they do not provide the same legal certainty as a new treaty, it is the relative ease of with which these declarations are accepted that allows for a quicker legal effect, in terms of understanding the treaty in accordance with the intention of its parties.

Keywords: judicial activism; interpretative declarations; subsequent agreements; interpretation of treaties; investment arbitration; International Law Commission 
